\title{
Interleukin-10 rs2227307 and CXCR2 rs1126579 polymorphisms modulate the predisposition to septic shock
}

\author{
Cristina Padre Cardoso', Argenil José de Assis de Oliveira² ${ }^{2}$ Fernando Antônio Botoni' ${ }^{2,3}$, \\ Isabela Cristina Porto Rezende ${ }^{4}$, Jose Carlos Alves-Filho ${ }^{5}$, Fernando de Queiroz Cunha ${ }^{5}$, \\ Juliana de Assis Silva Gomes Estanislau ${ }^{4}$, Luiz Alexandre Viana Magno ${ }^{6,7}$, Fabricio Rios-Santos ${ }^{8 /+}$
}

\begin{abstract}
'Laboratório de Farmacogenômica e Epidemiologia Molecular, Universidade Estadual de Santa Cruz, Ilhéus, BA, Brasil
${ }^{2}$ Hospital Risoleta Tolentino Neves, Belo Horizonte, MG, Brasil ${ }^{3}$ Programa de Pós-Graduação em Ciências da Saúde, Departamento de Clínica Médica, Infectologia e Medicina Tropical ${ }^{6}$ Instituto Nacional de Ciência e Tecnologia de Medicina Molecular, Faculdade de Medicina ${ }^{4}$ Departamento de Morfologia, Instituto de Ciências Biológicas, Universidade Federal de Minas Gerais, Belo Horizonte, MG, Brasil ${ }^{5}$ Departamento de Farmacologia, Escola de Medicina de Ribeirão Preto, Universidade de São Paulo, Ribeirão Preto, SP, Brasil ${ }^{7}$ Mestrado em Tecnologia da Informação Aplicada a Biologia Computacional, Faculdade Infórium de Tecnologia, Belo Horizonte, MG, Brasil

${ }^{8}$ Departamento de Ciências Básicas em Saúde, Faculdade de Medicina, Universidade Federal de Mato Grosso, Cuiabá, MT, Brasil
\end{abstract}

Despite major improvements in its treatment and diagnosis, sepsis is still a leading cause of death and admittance to the intensive care unit (ICU). Failure to identify patients at high risk of developing septic shock contributes to an increase in the sepsis burden and rapid molecular tests are currently the most promising avenue to aid in patient risk determination and therapeutic anticipation. The primary goal of this study was to evaluate the genetic susceptibility that affects sepsis outcome in 72 sepsis patients admitted to the ICU. Seven polymorphisms were genotyped in key inflammatory response genes in sepsis, including tumour necrosis factor- $\alpha$, interlelukin (IL)-1 $\beta$, IL-10, IL-8, Tolllike receptor 4, CXCR1 and CXCR2. The primary finding showed that patients who were homozygous for the major A allele in IL-10 rs1800896 had almost five times higher chance to develop septic shock compared to heterozygotes. Similarly, selected clinical features and CXCR2 rs1126579 single nucleotide polymorphisms modulated septic shock susceptibility without affecting survival. These data support the hypothesis that molecular testing has clinical usefulness to improve sepsis prognostic models. Therefore, enrichment of the ICU portfolio by including these biomarkers will aid in the early identification of sepsis patients who may develop septic shock.

Key words: sepsis - septic shock - biomarkers - polymorphisms - inflammation - intensive care unit

Sepsis is a complex medical condition triggered by an infection that spreads through the bloodstream. This condition leads to a systemic and uncontrolled inflammatory response that causes multiple organ failure (Dellinger et al. 2013). Despite improvements in treatment and diagnosis, sepsis is still a leading cause of death. Approximately 750,000 individuals in the United States of America develop this condition annually and a third of the patients do not survive (Angus et al. 2001). Furthermore, sepsis is costly because patients who develop septic shock spend longer time in the intensive care unit (ICU) and have an increased risk of death (Schmid et al. 2002, Arnold et al. 2014).

Sepsis involves a complex interplay between pro and antiinflammatory mediators and an unpredictable host defence response. Despite recent efforts to elucidate biomarkers of the transition from severe sepsis to septic shock (Faix 2013, Alder et al. 2014), it is not yet

doi: 10.1590/0074-02760150003

Financial support: $\mathrm{CNPq}$

CPC and AJAO contributed equally to this work. JASGE is CNPq

research fellow and LAVM is a postdoctoral fellow of CAPES.

+ Corresponding author: fabriciorios@yahoo.com

Received 6 January 2015

Accepted 30 April 2015 clear why similar pathogen infections result in distinct outcomes (Maslove \& Wong 2014). In this regard, variations in genes encoding proteins with significant immunological roles may be useful in determining the patient immunogenetic background, which could be responsible for interindividual susceptibility to sepsis complications. For example, an over-stimulated immune system in a sepsis patient could be related to genetic polymorphisms affecting protein function and gene expression, resulting in excessive proinflammatory responses (Arcaroli et al. 2005). Accordingly, single nucleotide polymorphisms (SNPs) within the tumour necrosis factor (TNF)- $\alpha$ gene promoter, such as $-308(\mathrm{~A} / \mathrm{G})$ (also known as allele TNF2), have been associated with increased promoter activity (Wilson et al. 1997) and increased TNF- $\alpha$ plasma levels in response to lipopolysaccharides (Louis et al. 1998). These biological changes increase the severity of sepsis, including mortality (Mira et al. 1999). Additionally, other SNPs that affect sepsis outcome have been identified in the Toll-like receptor (TLR) signalling pathway, heat shock proteins, coagulation and antiinflammatory cytokines [reviewed by Arcaroli et al. 2005)].

Current sepsis research has focused on quick molecular-based tests to identify subjects at a high risk of developing septic shock immediately after ICU admission. It is expected that this strategy will provide a rationale for early drug therapy and better sepsis prognosis (Reinhart et al. 2012). Although valuable insights have 
been gained from the study of genetic heterogeneity in the immune system on sepsis, only a few studies have addressed the clinical feasibility of molecular testing for risk stratification in an ICU. Here, we genotyped seven polymorphisms from pro and antiinflammatory genes in hospitalised sepsis patients to investigate their potential utility in future therapeutic trials.

\section{SUBJECTS, MATERIALS AND METHODS}

Patients and clinical data - From October 2012-October 2013, 72 randomly selected sepsis patients were followed. These patients were admitted to the Risoleta Tolentino Neves Hospital ICU in Belo Horizonte, Brazil. Sepsis diagnosis was based on the criteria established by the American College of Chest Physicians (Bone et al. 1992) and the 2001 International Sepsis Definitions Conference (Levy et al. 2003). Patients were further diagnosed with severe sepsis (acute organ dysfunction) or septic shock (refractory hypotension and hyperlactataemia) (Rivers et al. 2001). All subjects were monitored until hospital discharge or death.

Demographic characteristics and clinical data, including Acute Physiology and Chronic Health Evaluation II (APACHE II), Sequential Organ Failure Assessment (SOFA), source of infection, laboratory results, microbiology and ICU mortality were obtained after sepsis diagnosis. Exclusion criteria were the following: under 18 years old, pregnancy, severe chronic respiratory disease, severe chronic liver disease (defined as a Child-Pugh score of 0.10 ), cancer, acquired immune deficiency syndrome and high dose immunosuppressive therapy. All enrolled subjects provided written informed consent approved by the Ethical Committee of Federal University of Minas Gerais (protocol 03182712.2.00005149/2011 CAAE: 03182712.2.0000.5149/2012).
SNP selection, sample collection and genotyping Seven SNPs were studied in genes encoding proteins implicated in systemic inflammatory responses to sepsis (Table I). Increased levels of TNF- $\alpha$, interleukin (IL)$1 \beta$ and IL- 8 are thought to be key triggers of the initial hyperinflammation in sepsis, while IL-10 is a biomarker for sepsis-induced immunoparalysis, a clinical stage strongly associated with sepsis-related death (Boomer et al. 2011). SNPs in important cytokine (CXCR1 and CXCR2) and pathogen recognition receptors (TLR4) were also evaluated. The polymorphisms examined were rs1800629 (TNF- $\alpha)$, rs1143634 (IL-1 $\beta)$, rs1800896 (IL-10), rs2227307 (IL-8), rs1927911 (TLR4), rs16858811 (CXCR1) and rs1126579 (CXCR2).

Genomic DNA was extracted from peripheral blood using the Flexigene Kit (Qiagen, Germany) according to the manufacturer's instructions. DNA concentration and quality were evaluated using a NanoDrop 1000 (Thermo Scientific, USA). Genotyping was performed using Applied Biosystems TaqMan assays. Briefly, 50 ng DNA was used for the real-time polymerase chain reaction (PCR) genotyping. PCR was performed on the CFX96TM RealTime PCR Detection System (Bio-Rad, USA) with the following parameters: $10 \mathrm{~min}$ at $95^{\circ} \mathrm{C}$ and 50 cycles in two steps, $15 \mathrm{~s}$ at $95^{\circ} \mathrm{C}$ and $1 \mathrm{~min}$ at $60^{\circ} \mathrm{C}$. Fluorescence was read after the completion of each PCR cycle and allele discrimination was performed by the CFX Manager software (Bio-Rad). Quality control was implemented to ensure data accuracy by retyping at least $10 \%$ of the $\mathrm{d}$ sample.

Statistical analysis - Because all data occurred in a Gaussian distribution, a student's $t$ test and ANOVA were performed for the quantitative data and chi-squared tests were performed for categorical variables in SPSS v.20. Comparison of the observed genetic frequencies among groups was performed using UNPHASED (v.3.1.7) (Dud-

TABLE I

Characteristics of the genes and polymorphisms evaluated by this study

\begin{tabular}{|c|c|c|c|c|c|}
\hline Gene & Function & SNP & $\begin{array}{c}\text { Gene } \\
\text { location }\end{array}$ & $\begin{array}{l}\text { Major/minor } \\
\text { allele }\end{array}$ & HWE p \\
\hline CXCR1 & Receptor $\alpha$ for the chemokine IL- 8 & rs16858811 & Exon & $\mathrm{C} / \mathrm{T}$ & 0.0045 \\
\hline CXCR2 & Receptor $\beta$ for the chemokine IL- 8 & rs1126579 & Utr 3' & $\mathrm{G} / \mathrm{T}$ & 0.1113 \\
\hline TLR4 & $\begin{array}{l}\text { TLR associated with pathogen recognition } \\
\text { and activation of innate immunity }\end{array}$ & rs1927911 & Intron & $\mathrm{A} / \mathrm{G}$ & 0.5242 \\
\hline$I L-1 \beta$ & $\begin{array}{c}\text { Proinflammatory cytokine produced by } \\
\text { activated macrophages }\end{array}$ & rs1143634 & Intragenic & $\mathrm{C} / \mathrm{T}$ & 0.3461 \\
\hline$I L-8$ & $\begin{array}{c}\text { Chemotactic factor for neutrophils and } \\
\text { other granulocytes }\end{array}$ & rs2227307 & Intron & $\mathrm{T} / \mathrm{G}$ & 0.5242 \\
\hline$I L-10$ & $\begin{array}{l}\text { Antiinflammatory cytokine produced } \\
\text { by monocytes and lymphocytes }\end{array}$ & rs1800896 & Promoter & $\mathrm{A} / \mathrm{G}$ & 0.9025 \\
\hline$T N F-\alpha$ & $\begin{array}{c}\text { Proinflammatory cytokine that attracts } \\
\text { neutrophils }\end{array}$ & rs 1800629 & Intron & $\mathrm{G} / \mathrm{A}$ & 0.4092 \\
\hline
\end{tabular}

Hardy-Weinberg equilibrium (HWE) p-value in bold was considered deviated from Hardy-Weinberg principle; IL: interleukin; SNP: single nucleotide polymorphisms; TLR: Toll-like receptor; TNF: tumour necrosis factor. 
bridge 2008). Odds ratio (OR) values shown in the tables were obtained using the ancestral genotype or allele as a reference (displayed as OR = 1). HAPLOVIEW (v.4.1) was used to evaluate the deviation from the Hardy-Weinberg equilibrium (HWE) (Barrett et al. 2005). All tests were two-tailed and the p-level for significance was set at 0.05 .

\section{RESULTS}

Out of the 72 sepsis patients included in this study (average age of $52.7 \pm 19.0$ years and $10.6 \pm 8.4$ days at ICU), $63.9 \%$ (46) were male (Table II). According to the clinical assessment, $20.8 \%(15)$ of the patients presented with severe sepsis and $79.2 \%$ (57) presented with septic shock. Clinical variables were not significantly different between these groups. Conversely, we identified robust influence of the clinical data on the death risk. Thirteen (18.1\%) septic shock patients did not survive and they appeared to be predisposed due to increased age (66 \pm 18.9 years; $p=0.005)$, female gender $(30.8 \%$ vs. $10.9 \%$ of men; $\mathrm{p}=0.035)$, fewer days in the ICU $(4.31 \pm 3.22$; $\mathrm{p}=0.002)$, higher APACHE II and SOFA scores $[36.7 \pm$ $5.7(\mathrm{p}=0.0001)$ and $13.2 \pm 3.1(\mathrm{p}=0.0001)$, respectively] and laboratory results (Table II).

Depending on the SNP, we successfully genotyped approximately $95-99 \%$ of the samples. We found that only CXCR1 rs16858811 deviated from the HWE ( $\mathrm{p}<$ 0.01 ) (Table I). We first compared the genotype and allele frequencies between patients with severe sepsis and septic shock. According to our findings, the frequencies of the $I L-10$ rs1800896 and CXCR2 rs1126579 SNPs were heterogeneously distributed among the patient subgroups (Table III). For instance, patients carrying the AA genotype from $I L-10$ rs1800896 had almost five times increased risk to develop septic shock compared to heterozygotes $[\mathrm{p}=0.0083$; OR $=4.85 ; 95 \%$ confidence interval $(\mathrm{CI})=1.67-14.03]$. The risk was also greater for carriers of the A allele $(\mathrm{p}=0.009 ; \mathrm{OR}=2.69 ; 95 \% \mathrm{CI}=$ 1.26-5.72). For $C X C R 2$ rs1126579, we only found significant differences through allele comparisons, with carriers of the $\mathrm{T}$ allele at greater risk of septic shock $(\mathrm{p}=$ $0.0251 ; \mathrm{OR}=2.32 ; 95 \% \mathrm{CI}=1.10-4.91$ ).

Contrary to clinical data, none of the genetic markers predisposed the patients to a higher risk of death, even though the ancestral genotype $(\mathrm{p}=0.015)$ and allele $(\mathrm{p}=$ 0.0148 ) from $I L-1 \beta$ rs1143634 was frequently found in patients with an APACHE score greater than 25 (Table IV).

\section{DISCUSSION}

Understanding why certain patients are at greater risk for poorer sepsis outcomes goes far beyond the microorganism's infection and damage to the host tissues. Recent studies have suggested that inherited factors play a significant role in the predisposition to sepsis-related complications by affecting hyperinflammatory or hypoinflammatory responses to infection (Arcaroli et al. 2005, Baier et al. 2006, Abu-Maziad et al. 2010, Man et al. 2013). The primary goal of this study was to evaluate genetic predispositions that influence sepsis outcome. By genotyping polymorphisms in key inflammatory response genes in sepsis, we identified patients at a high risk to develop septic shock. Therefore, our findings support the hypothesis that molecular testing is clinically useful to improving sepsis prognostic models.

Sepsis remains a public health issue, perhaps due to the lack of valid biomarkers to assess an individual's risk for poor prognosis upon infection. Here, we found that homozygotes for the major A allele in $I L-10$ rs1800896 have an almost five-times increased risk of developing septic shock compared to heterozygous patients. This finding is consistent with those of Baier et al. (2006) and Abu-Maziad et al. (2010), in which infants with the $I L-10$ rs1800896 AA genotype had an increased incidence of late-onset sepsis, while Treszl et al. (2003) did not observe a similar association. IL-10 is a potent antiinflammatory cytokine that increases the severity of systemic infection in newborn infants at high levels (Romagnoli et al. 2001, Ng et al. 2003). Experimental evidence has shown that IL-10 is a preeminent therapeutic candidate for irreversible septic shock (Latifi et al. 2002). How the A allele of $I L-10$ rs1800896 contributes to increased risk of septic shock is unclear. This SNP, also known as $-1082(\mathrm{~A} / \mathrm{G})$, is located within the $I L-10$ promoter region and is therefore presumed to affect the gene's transcriptional activity. Because individuals carrying the A allele have decreased circulating levels of IL-10 (Schaaf et al. 2003), we hypothesise that AA homozygotes are prone to proinflammatory responses, which favour septic shock. However, further measurement of circulating IL-10 concentrations and genotyping of other IL-10 promoter polymorphisms [such as microsatellites, $-819(\mathrm{C} / \mathrm{T})$ and -592 $(\mathrm{C} / \mathrm{A})]$ should be examined to refine this assumption.

CXCR2 is the IL- $8 \beta$ receptor that mediates neutrophil migration to inflammation sites. To our knowledge, this is the first report of the CXCR2 rs1126579 SNP as a septic shock biomarker. Carriers of the minor $\mathrm{T}$ allele had a two-fold increased risk for developing septic shock compared to carriers of the $\mathrm{C}$ allele. The rs1126579 SNP is located in the $3^{\prime}$ untranslated region of the CXCR2 gene and no data on its impact on CXCR 2 activity have been described to date.

Recent advances in the understanding of sepsis suggested that after initial hyperinflammation, the immune system shifts to a profoundly suppressed state known as sepsis-induced immunoparalysis (Hotchkiss \& Karl 2003, Boomer et al. 2011). Immunoparalysis accounts for the majority of sepsis-related mortality. None of the polymorphisms investigated here showed a significant effect on mortality rate of sepsis patients. These results suggest that these SNPs' scores have a weak, if any, influence on immunoparalysis mechanisms. Investigation into other genetic polymorphisms is important to identify biomarkers of sepsis-related death. Conversely, we found clinical, demographic and laboratory data associated with decreased survival. For example, most younger patients survived to hospital discharge. Importantly, age and genotype were independent risk factors, as multivariate analysis showed no significant influence of age on the genotype's effect (data not shown). Nevertheless, we expect that in a large-scale population, combining the individual SNP or gene-gene interaction risk score with clinical factors may increase the predictive ability of molecular testing (Man et al. 2013). 


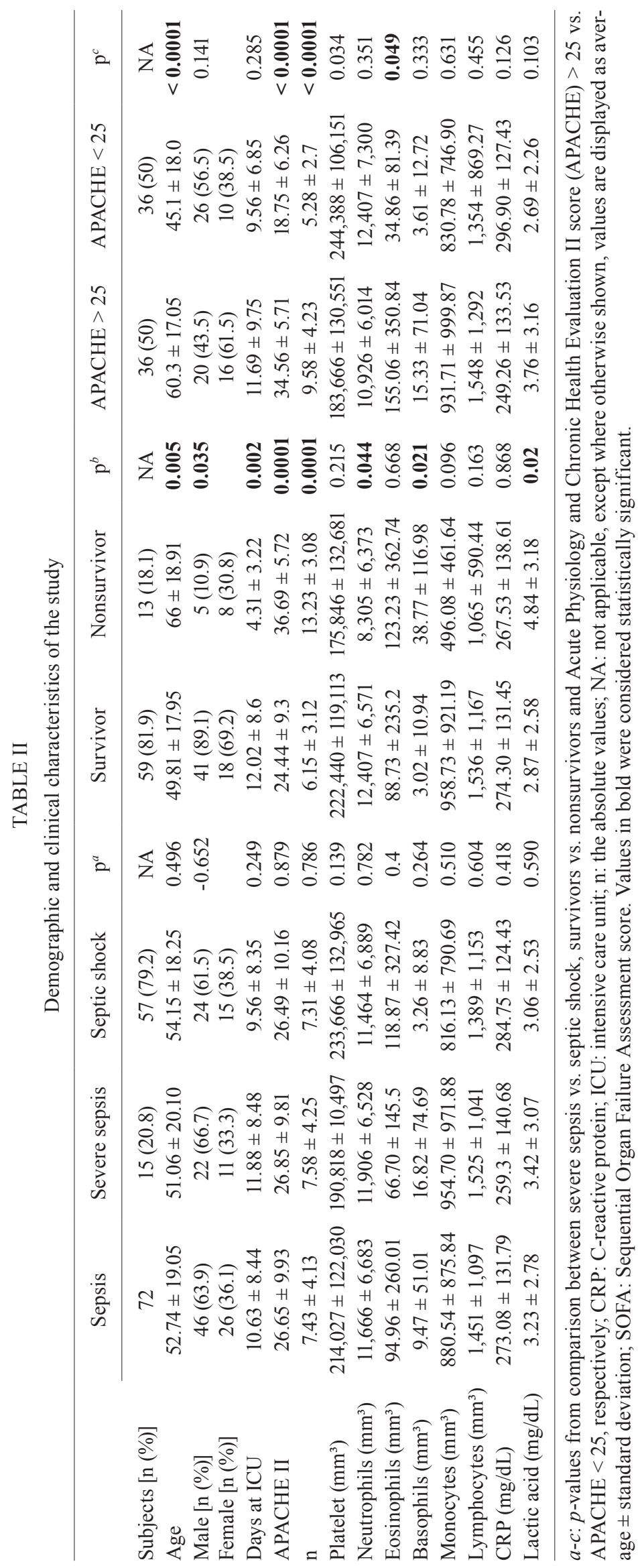


TABLE III

Association analysis of single nucleotide polymorphisms (SNPs) between sepsis patients

\begin{tabular}{|c|c|c|c|c|c|}
\hline Gene (SNP) & $\begin{array}{l}\text { Sepsis } \\
\mathrm{n}(\%)\end{array}$ & $\begin{array}{c}\text { Severe sepsis } \\
n(\%)\end{array}$ & $\begin{array}{c}\text { Septic shock } \\
\text { n }(\%)\end{array}$ & $\begin{array}{c}\text { OR } \\
(95 \% \mathrm{CI})\end{array}$ & $\mathrm{p}$ \\
\hline \multicolumn{6}{|l|}{$\begin{array}{l}\text { CXCR1 } \\
\text { rs16858811 }\end{array}$} \\
\hline AA & $49(71.01)$ & $22(68.75)$ & $27(72.97)$ & 1 & $0.700^{a}$ \\
\hline $\mathrm{AC}$ & $20(28.99)$ & $10(31.25)$ & $10(27.03)$ & $0.81(0.28-2.30)$ & \\
\hline $\mathrm{CC}$ & $0(0)$ & $0(0)$ & $0(0)$ & NA & \\
\hline A & $118(85.5)$ & $54(84.38)$ & 64 (86.49) & 1 & $0.725^{b}$ \\
\hline $\mathrm{C}$ & $20(14.5)$ & $10(15.62)$ & $10(13.51)$ & $0.84(0.32-2.17)$ & \\
\hline \multicolumn{6}{|l|}{$\begin{array}{l}\text { CXCR2 } \\
\text { rs1126579 }\end{array}$} \\
\hline $\mathrm{CC}$ & $34(49.28)$ & $12(37.5)$ & $22(59.46)$ & 1 & $0.0617^{a}$ \\
\hline $\mathrm{CT}$ & $29(42.03)$ & $15(46.88)$ & $14(37.84)$ & $0.51(0.18-1.40)$ & \\
\hline $\mathrm{TT}$ & $6(8.7)$ & $5(15.62)$ & $1(2.7)$ & $0.11(0.01-1.04)$ & \\
\hline $\mathrm{C}$ & $97(70.29)$ & $39(60.94)$ & $58(78.38)$ & 1 & $0.0251^{b}$ \\
\hline $\mathrm{T}$ & $41(29.71)$ & $25(39.06)$ & $16(21.62)$ & $0.43(0.20-0.90)$ & \\
\hline \multicolumn{6}{|l|}{$\begin{array}{l}\text { TLR4 } \\
\text { rs1927911 }\end{array}$} \\
\hline AA & $16(23.19)$ & $8(25)$ & $8(21.62)$ & 1 & $0.1045^{a}$ \\
\hline $\mathrm{AG}$ & $27(39.13)$ & $16(50)$ & $11(29.73)$ & $0.69(0.19-2.38)$ & \\
\hline GG & $26(37.68)$ & $8(25)$ & $18(48.65)$ & $2.25(0.62-8.14)$ & \\
\hline A & $59(42.75)$ & $32(5)$ & 27 (36.49) & 1 & $0.109^{b}$ \\
\hline $\mathrm{G}$ & $79(57.25)$ & $32(5)$ & $47(63.51)$ & $1.74(0.88-3.44)$ & \\
\hline \multicolumn{6}{|l|}{$\begin{array}{l}I L-1 \beta \\
\mathrm{rs} 1143634\end{array}$} \\
\hline GG & $49(71.01)$ & $24(75)$ & $25(67.57)$ & 1 & $0.758^{a}$ \\
\hline GA & $18(26.09)$ & 7 (21.9) & $11(29.73)$ & $1.51(0.50-4.53)$ & \\
\hline AA & $2(2.9)$ & $1(3.1)$ & $1(2.7)$ & $0.96(0.05-16.23)$ & \\
\hline $\mathrm{G}$ & $116(84)$ & $55(85.94)$ & $61(82.43)$ & 1 & $0.573^{b}$ \\
\hline A & $22(15.94)$ & $9(14.06)$ & $13(17.57)$ & $1.30(0.51-3.28)$ & \\
\hline \multicolumn{6}{|l|}{$I L-8$} \\
\hline \multicolumn{6}{|l|}{ rs2227307 } \\
\hline GG & $20(28.99)$ & $7(21.88)$ & $13(35.14)$ & 1 & $0.459^{a}$ \\
\hline GT & $38(55.07)$ & $19(59.37)$ & $19(51.35)$ & $0.54(0.17-1.64)$ & \\
\hline TT & $11(15.94)$ & $6(18.75)$ & $5(13.51)$ & $0.45(0.1-2.01)$ & \\
\hline G & $78(56.52)$ & $33(51.56)$ & $45(60.81)$ & 1 & $0.274^{b}$ \\
\hline $\mathrm{T}$ & $60(43.48)$ & $31(48.44)$ & $29(39.19)$ & $0.69(0.34-1.35)$ & \\
\hline \multicolumn{6}{|l|}{$I L-10$} \\
\hline \multicolumn{6}{|l|}{ rs1800896 } \\
\hline AA & $33(47.83)$ & $9(28.1)$ & $24(64.86)$ & 1 & $\mathbf{0 . 0 0 8 3}^{a}$ \\
\hline $\mathrm{AG}$ & $51(44.93)$ & $20(62.5)$ & $11(29.73)$ & $0.21(0.07-0.59)$ & \\
\hline GG & $5(7.24)$ & $3(9.4)$ & $2(5.4)$ & $0.25(0.03-1.75)$ & \\
\hline A & $97(70.29)$ & $38(59.38)$ & $59(79.73)$ & 1 & $\mathbf{0 . 0 0 9})^{b}$ \\
\hline $\mathrm{G}$ & $41(29.71)$ & $26(40.62)$ & $15(20.27)$ & $0.37(0.17-0.79)$ & \\
\hline \multicolumn{6}{|l|}{$\begin{array}{l}T N F-\alpha \\
\text { rs } 1800629\end{array}$} \\
\hline GG & $54(78.26)$ & $26(81.26)$ & $28(75.68)$ & 1 & $0.323^{a}$ \\
\hline GA & $14(20.29)$ & $5(15.62)$ & $9(24.32)$ & $1.67(0.49-5.64)$ & \\
\hline AA & $1(1.44)$ & $1(3.12)$ & $0(0)$ & NA & \\
\hline G & $122(88.4)$ & $57(89.06)$ & $65(87.84)$ & 1 & $0.822^{b}$ \\
\hline A & $16(11.6)$ & $7(10.94)$ & $9(12.16)$ & $1.13(0.39-3.22)$ & \\
\hline
\end{tabular}

$a, b$ : genotype and allele comparisons, respectively; CI: confidence interval; IL: interleukin; n: absolute values; NA: not applicable; OR: odds ratio; TLR: Toll-like receptor; TNF: tumour necrosis factor. Values in bold were considered statistically significant. 
TABLE IV

Association analysis of single nucleotide polymorphisms (SNPs) between survivors and nonsurvivors and APACHE $>25$ of severe sepsis patients

\begin{tabular}{|c|c|c|c|c|c|c|c|c|}
\hline Gene (SNP) & $\begin{array}{c}\text { Nonsurvivor } \\
\text { n (\%) }\end{array}$ & $\begin{array}{l}\text { Survivor } \\
\mathrm{n}(\%)\end{array}$ & $\begin{array}{c}\text { OR } \\
(95 \% \mathrm{CI})\end{array}$ & $\mathrm{p}^{a}$ & $\begin{array}{c}\text { APACHE }>25 \\
\text { n (\%) }\end{array}$ & $\begin{array}{c}\text { APACHE }<25 \\
\text { n (\%) }\end{array}$ & $\begin{array}{c}\text { OR } \\
(95 \% \mathrm{CI})\end{array}$ & $\mathrm{p}^{b}$ \\
\hline \multicolumn{9}{|l|}{$\begin{array}{l}\text { CXCR1 } \\
\text { rs16858811 }\end{array}$} \\
\hline AA & $7(53.85)$ & $42(75)$ & 1 & $0.142^{c}$ & $22(62.86)$ & $27(79.41)$ & 1 & $0.127^{c}$ \\
\hline $\mathrm{AC}$ & $6(46.15)$ & $14(25)$ & $2.57(0.73-8.94)$ & & $13(37.14)$ & $7(20.59)$ & $2.27(0.77-6.69)$ & \\
\hline $\mathrm{CC}$ & $0(0)$ & $0(0)$ & - & & $0(0)$ & $0(0)$ & - & \\
\hline A & $20(76.29)$ & $98(87.5)$ & 1 & $0.189^{d}$ & $57(81.43)$ & $61(89.71)$ & 1 & $0.1643^{d}$ \\
\hline $\mathrm{C}$ & $6(23.08)$ & $14(12.5)$ & $2.1(0.72-6.12)$ & & $13(18.57)$ & $7(10.29)$ & $1.98(0.74-5.33)$ & \\
\hline \multicolumn{9}{|l|}{$\begin{array}{l}\text { CXCR2 } \\
\text { rs } 1126579\end{array}$} \\
\hline $\mathrm{CC}$ & $7(53.85)$ & $27(48.21)$ & 1 & $0.934^{c}$ & $18(51.43)$ & $16(47.06)$ & 1 & $0.933^{c}$ \\
\hline $\mathrm{CT}$ & $5(38.46)$ & $24(42.86)$ & $0.80(0.22-2.86)$ & & $14(4)$ & $15(44.12)$ & $0.82(0.30-2.23)$ & \\
\hline TT & $1(7.69)$ & $5(8.93)$ & $0.77(0.07-7.71)$ & & $3(8.57)$ & $3(8.88)$ & $0.88(0.15-5.04)$ & \\
\hline $\mathrm{C}$ & $19(73.08)$ & $78(69.64)$ & 1 & $0.728^{d}$ & $50(71.43)$ & $47(69.12)$ & 1 & $0.7665^{d}$ \\
\hline $\mathrm{T}$ & $7(26.92)$ & $34(30.36)$ & $0.84(0.31-2.19)$ & & $20(28.57)$ & $21(30.88)$ & $0.89(0.43-1.85)$ & \\
\hline \multicolumn{9}{|l|}{$\begin{array}{l}\text { TLR4 } \\
\text { rs1927911 }\end{array}$} \\
\hline AA & $2(15.38)$ & $14(25)$ & 1 & $0.410^{c}$ & $8(22.86)$ & $8(23.53)$ & 1 & $0.314^{c}$ \\
\hline $\mathrm{AG}$ & $4(30.77)$ & $23(41.07)$ & $1.21(0.19-7.53)$ & & $11(31.43)$ & $16(47.06)$ & $0.68(0.19-2.38)$ & \\
\hline GG & $7(53.85)$ & $19(33.93)$ & $2.57(0.46-14.35)$ & & $16(45.71)$ & $10(29.41)$ & $1.6(0.45-5.63)$ & \\
\hline A & $8(30.77)$ & $51(45.54)$ & 1 & $0.164^{d}$ & $27(38.57)$ & $32(47.06)$ & 1 & $0.3134^{d}$ \\
\hline $\mathrm{G}$ & $18(69.23)$ & $61(54.46)$ & $1.88(0.75-4.68)$ & & $43(61.43)$ & $36(52.94)$ & $1.42(0.72-2.78)$ & \\
\hline \multicolumn{9}{|l|}{$\begin{array}{l}I L-1 \beta \\
\text { rs1143634 }\end{array}$} \\
\hline GG & $11(84.62)$ & $38(67.86)$ & 1 & $0.129^{c}$ & $30(85.71)$ & $19(55.88)$ & 1 & $\mathbf{0 . 0 1 5}^{c}$ \\
\hline GA & $1(7.69)$ & $17(30.36)$ & $0.20(0.02-1.70)$ & & $4(11.43)$ & $14(41.18)$ & $0.18(0.05-0.63)$ & \\
\hline $\mathrm{AA}$ & $1(7.69)$ & $1(1.78)$ & $3.45(0.19-59.84)$ & & $1(2.85)$ & $1(2.94)$ & $0.63(0.03-10.74)$ & \\
\hline G & $23(88.46)$ & $93(83.04)$ & 1 & $0.481^{d}$ & $64(91.43)$ & $52(76.47)$ & 1 & $\mathbf{0 . 0 1 4 8}^{d}$ \\
\hline $\mathrm{A}$ & $3(11.54)$ & $19(16.96)$ & $0.63(0.17-2.34)$ & & $6(8.57)$ & $16(23.53)$ & $0.30(0.11-0.83)$ & \\
\hline \multicolumn{9}{|l|}{$\begin{array}{l}I L-8 \\
\text { rs2227307 }\end{array}$} \\
\hline GG & $2(15.38)$ & $18(32.14)$ & 1 & $0.412^{c}$ & $11(31.43)$ & $9(26.47)$ & 1 & $0.870^{c}$ \\
\hline GT & $8(61.54)$ & $30(53.57)$ & $2.4(0.45-12.57)$ & & $19(54.29)$ & $19(55.88)$ & $0.81(0.27-2.42)$ & \\
\hline $\mathrm{TT}$ & $3(23.08)$ & $8(14.29)$ & $3.37(0.46-24.29)$ & & $5(14.29)$ & $6(17.65)$ & $0.68(0.15-2.98)$ & \\
\hline G & $12(46.15)$ & $66(58.93)$ & 1 & $0.238^{d}$ & $41(58.57)$ & $37(54.41)$ & 1 & $0.6221^{d}$ \\
\hline $\mathrm{T}$ & $14(53.85)$ & $46(41.07)$ & $1.67(0.70-3.94)$ & & $29(41.43)$ & $31(45.59)$ & $0.84(0.43-1.65)$ & \\
\hline \multicolumn{9}{|l|}{$\begin{array}{l}I L-10 \\
\text { rs1800896 }\end{array}$} \\
\hline $\mathrm{TT}$ & $27(48.21)$ & $6(46.15)$ & 1 & $0.306^{c}$ & $15(42.86)$ & $18(52.94)$ & 1 & $0.687^{c}$ \\
\hline $\mathrm{TC}$ & $24(42.86)$ & $7(53.85)$ & $1.31(0.38-4.45)$ & & $17(48.57)$ & $14(41.18)$ & $0.68(0.19-2.38)$ & \\
\hline $\mathrm{CC}$ & $5(8.93)$ & $0(0)$ & NA & & $3(8.57)$ & $2(5.88)$ & $1.6(0.45-5.63)$ & \\
\hline $\mathrm{T}$ & $19(73.08)$ & $78(69.64)$ & 1 & $0.728^{d}$ & $47(67.14)$ & $50(73.53)$ & 1 & $0.4113^{d}$ \\
\hline $\mathrm{C}$ & $7(26.92)$ & $34(30.36)$ & $0.84(0.32-2.19)$ & & $23(32.86)$ & $18(26.47)$ & $1.35(0.65-2.83)$ & \\
\hline \multicolumn{9}{|l|}{$\begin{array}{l}T N F-\alpha \\
\text { rs } 1800629\end{array}$} \\
\hline GG & $10(76.92)$ & $44(78.57)$ & 1 & $0.1699^{c}$ & $27(77.14)$ & $27(79.41)$ & 1 & $0.5036^{c}$ \\
\hline GA & $2(15.38)$ & $12(21.43)$ & $0.73(0.14-3.80)$ & & $7(0.2)$ & $7(0.2)$ & $1(3.0-3.24)$ & \\
\hline $\mathrm{AA}$ & $1(7.7)$ & $0(0)$ & NA & & $1(0.02)$ & $0(0)$ & NA & \\
\hline G & $22(84.62)$ & $100(89.29)$ & 1 & $0.5163^{d}$ & $61(87.14)$ & $61(89.71)$ & 1 & $0.6378^{d}$ \\
\hline A & $4(15.38)$ & $12(10.71)$ & $1.28(0.45-3.67)$ & & $9(12.86)$ & $7(10.29)$ & $1.28(0.45-3.67)$ & \\
\hline
\end{tabular}

$a, b$ : p-values from comparison between survivors vs. nonsurvivors and Acute Physiology and Chronic Health Evaluation II score (APACHE) $>25$ vs. APACHE < 25, respectively; $c, d$ : genotype and allele comparisons, respectively; CI: confidence interval; IL: interleukin; n: the absolute values; NA: not applicable; OR: odds ratio; TLR: Toll-like receptor; TNF: tumour necrosis factor. Values in bold were considered statistically significant. 
Overall, a limitation of this study was the lack of comprehensive clinical information, such as the causative pathogen, initial infection site and the gap before treatment initiation. However, this caveat reveals that the positive genetic markers identified may be useful in assessing septic shock risk even when these data are not yet established. Nevertheless, we encourage further study aimed at investigating the clinical usefulness of these SNPs in specific infections, which may reveal reliable predictive models. Moreover, considering that some of the patients' demographic and clinical factors influence sepsis predisposition, it would be interesting to stratify our data to enhance input score reliability. However, the sample pool we recruited was too small to enable such an approach.

In conclusion, our findings revealed that $I L-10$ rs1800896, CXCR2 rs1126579 and selected clinical features can be used as markers for septic shock development, but not for decreased survival. Therefore, sepsis prognostic models including these biomarkers appear can enable the early identification of sepsis patients who may become septic shock cases. Although other studies are required to evaluate the accuracy of these data in different populations, a recent meta-analysis found that IL-10 polymorphisms are associated with sepsis susceptibility in Caucasian and Asian populations (Pan et al. 2015). Furthermore, in addition to the risk of septic shock in this study possibly due to increased IL-10 plasma concentrations (Wang et al. 2011), it is now well-known that early sepsis diagnosis and correct clinical support compliance play a critical role in mortality (de Oliveira et al. 2013, van Zanten et al. 2014). In this context, we speculate that IL-10-induced immunosuppression may have a more important impact on the restriction of infection than on sepsis outcome. Finally, we believe that enrichment of the ICU portfolio by incorporating personalised strategies such as genetic testing for biomarkers of therapeutic response may improve the outcome of patients with sepsis and alleviate ICU demand in the future.

\section{REFERENCES}

Abu-Maziad A, Schaa K, Bell EF, Dagle JM, Cooper M, Marazita ML, Murray JC 2010. Role of polymorphic variants as genetic modulators of infection in neonatal sepsis. Pediatr Res 68: 323-329.

Alder MN, Lindsell CJ, Wong HR 2014. The pediatric sepsis biomarker risk model: potential implications for sepsis therapy and biology. Expert Rev Anti Infect Ther 12: 809-816.

Angus DC, Linde-Zwirble WT, Lidicker J, Clermont G, Carcillo J, Pinsky MR 2001. Epidemiology of severe sepsis in the United States: analysis of incidence, outcome and associated costs of care. Crit Care Med 29: 1303-1310.

Arcaroli J, Fessler MB, Abraham E 2005. Genetic polymorphisms and sepsis. Shock 24: 300-312.

Arnold R, Isserman J, Smola S, Jackson E 2014. Comprehensive assessment of the true sepsis burden using electronic health record screening augmented by natural language processing. Crit Care 18: P244.

Baier RJ, Loggins J, Yanamandra K 2006. IL-10, IL-6 and CD14 polymorphisms and sepsis outcome in ventilated very low birth weight infants. BMC Med 4: 10.

Barrett JC, Fry B, Maller J, Daly MJ 2005. Haploview: analysis and visualization of LD and haplotype maps. Bioinformatics 21: 263-265.
Bone RC, Sibbald WJ, Sprung CL 1992. The ACCP-SCCM consensus conference on sepsis and organ failure. Chest 101: 1481-1483.

Boomer JS, To K, Chang KC, Takasu O, Osborne DF, Walton AH, Bricker TL, Jarman SD, Kreisel D, Krupnick AS, Srivastava A, Swanson PE, Green JM, Hotchkiss RS 2011. Immunosuppression in patients who die of sepsis and multiple organ failure. JAMA 306: 2594-2605.

de Oliveira A, Cardoso C, Santos FR, Campos AP, Leite E, Stanislau J, Botoni F 2013. Predictors of mortality in patients with severe sepsis or septic shock in the ICU of a public teaching hospital. Crit Care 17 (Suppl. 4): P31.

Dellinger RP, Levy MM, Rhodes A, Annane D, Gerlach H, Opal SM, Sevransky JE, Sprung CL, Douglas IS, Jaeschke R, Osborn TM, Nunnally ME, Townsend SR, Reinhart K, Kleinpell RM, Angus DC, Deutschman CS, Machado FR, Rubenfeld GD, Webb S, Beale RJ, Vincent J-L, Moreno R 2013. Surviving Sepsis Campaign: international guidelines for management of severe sepsis and septic shock, 2012. Intensive Care Med 39: 165-228.

Dudbridge F 2008. Likelihood-based association analysis for nuclear families and unrelated subjects with missing genotype data. Hum Hered 66: 87-98.

Faix JD 2013. Biomarkers of sepsis. Crit Rev Clin Lab Sci 50: 23-36.

Hotchkiss RS, Karl IE 2003. The pathophysiology and treatment of sepsis. N Engl J Med 348: 138-150.

Latifi SQ, O'Riordan MA, Levine AD 2002. Interleukin-10 controls the onset of irreversible septic shock. Infect Immun 70: 4441-4446.

Levy MM, Fink MP, Marshall JC, Abraham E, Angus D, Cook D, Cohen J, Opal SM, Vincent J-L, Ramsay G 2003. 2001 SCCM/ ESICM/ACCP/ATS/SIS International Sepsis Definitions Conference. Crit Care Med 31: 1250-1256.

Louis E, Franchimont D, Piron A, Gevaert Y, Schaaf-Lafontaine N, Roland S, Mahieu P, Malaise M, De Groote D, Louis R, Belaiche J 1998. Tumour necrosis factor (TNF) gene polymorphism influences TNF-alpha production in lipopolysaccharide (LPS)stimulated whole blood cell culture in healthy humans. Clin Exp Immunol 113: 401-406.

Man M, Close SL, Shaw AD, Bernard GR, Douglas IS, Kaner RJ, Payen D, Vincent J-L, Fossceco S, Janes JM, Leishman AG, O'Brien L, Williams MD, Garcia JGN 2013. Beyond single-marker analyses: mining whole genome scans for insights into treatment responses in severe sepsis. Pharmacogenomics J 13: 218-226.

Maslove DM, Wong HR 2014. Gene expression profiling in sepsis: timing, tissue and translational considerations. Trends Mol Med 20: 204-213.

Mira JP, Cariou A, Grall F, Delclaux C, Losser MR, Heshmati F, Cheval C, Monchi M, Teboul JL, Riché F, Leleu G, Arbibe L, Mignon A, Delpech M, Dhainaut JF 1999. Association of TNF2, a TNF-alpha promoter polymorphism, with septic shock susceptibility and mortality: a multicenter study. JAMA 282: 561-568.

Ng PC, Li K, Wong RPO, Chui K, Wong E, Li G, Fok TF 2003. Proinflammatory and anti-inflammatory cytokine responses in preterm infants with systemic infections. Arch Dis Child Fetal Neonatal Ed 88: F209-F213.

Pan W, Zhang AQ, Yue CL, Gao JW, Zeng L, Gu W, Jiang JX 2015. Association between interleukin-10 polymorphisms and sepsis: a meta-analysis. Epidemiol Infect 143: 366-375.

Reinhart K, Bauer M, Riedemann NC, Hartog CS 2012. New approaches to sepsis: molecular diagnostics and biomarkers. Clin Microbiol Rev 25: 609-634.

Rivers E, Nguyen B, Havstad S, Ressler J, Muzzin A, Knoblich B, Peterson E, Tomlanovich M 2001. Early goal-directed therapy in 
the treatment of severe sepsis and septic shock. $N$ Engl J Med 345: 1368-1377.

Romagnoli C, Frezza S, Cingolani A, De Luca A, Puopolo M, De Carolis MP, Vento G, Antinori A, Tortorolo G 2001. Plasma levels of interleukin-6 and interleukin-10 in preterm neonates evaluated for sepsis. Eur J Pediatr 160: 345-350.

Schaaf BM, Boehmke F, Esnaashari H, Seitzer U, Kothe H, Maass M, Zabel P, Dalhoff K 2003. Pneumococcal septic shock is associated with the interleukin-10-1082 gene promoter polymorphism. Am J Respir Crit Care Med 168: 476-480.

Schmid A, Burchardi H, Clouth J, Schneider H 2002. Burden of illness imposed by severe sepsis in Germany. Eur J Health Econ 3: 77-82.

Treszl A, Kocsis I, Szathmári M, Schuler A, Héninger E, Tulassay T, Vásárhelyi B 2003. Genetic variants of TNF-[FC12]a, IL-1beta, IL-4 receptor [FC12]a-chain, IL-6 and IL-10 genes are not risk factors for sepsis in low-birth-weight infants. Biol Neonate 83: 241-245.

van Zanten AR, Brinkman S, Arbous MS, Abu-Hanna A, Levy MM, de Keizer NF, Netherlands Patient Safety Agency Sepsis Expert Group 2014. Guideline bundles adherence and mortality in severe sepsis and septic shock. Crit Care Med 42: 1890-1898.

Wang AH, Lam WJ, Han DY, Ding Y, Hu R, Fraser AG, Ferguson LR, Morgan AR 2011. The effect of IL-10 genetic variation and interleukin 10 serum levels on Crohn's disease susceptibility in a New Zealand population. Hum Immunol 72: 431-435.

Wilson AG, Symons JA, McDowell TL, McDevitt HO, Duff GW 1997. Effects of a polymorphism in the human tumor necrosis factor-alpha promoter on transcriptional activation. Proc Natl Acad Sci USA 94: 3195-3199. 
ERRATUM

Vol. 110 (4): 453-460, 2015.

p. 453

Interleukin-10 rs2227307 and CXCR2 rs1126579

polymorphisms modulate the predisposition to septic shock

should read:

Interleukin-10 rs1800896 and CXCR2 rs1126579

polymorphisms modulate the predisposition to septic shock 